\title{
Estimation of genetic parameters of boar taint; skatole and androstenone and their correlations with sexual maturation Håvard Tajet ${ }^{* 1,2}$, Øystein Andresen ${ }^{3}$ and THE Meuwissen ${ }^{2}$
}

Address: ${ }^{1}$ Norsvin, P.O.Box 504, NO-2304 Hamar, Norway, ${ }^{2}$ Norwegian University of Life Sciences, Ås, Norway and ${ }^{3}$ NVH, Oslo, Norway

* Corresponding author

from Prevention of Boar Taint in Pig Production: The 19th Symposium of the Nordic Committee for Veterinary Scientific Cooperation Gardermoen, Norway. 2 I-22 November 2005

Published: 7 August 2006

Acta Veterinaria Scandinavica 2006, 48(Suppl I):S9 doi:I0.II86/I75I-0I47-48-SI-S9

(C) 2006 Tajet et al.; licensee BioMed Central Ltd.

\begin{abstract}
Boar taint is mainly caused by two components; skatole (3-methylindole) and androstenone. By castrating the male pigs, boar taint will be avoided. In Norway, castration of pigs will no longer be permitted after 2009. This represents a substantial cost for the Norwegian swine production. Other Norwegian studies have shown that a large proportion of pigs are above the consumer detection limits for these two chemical components. The obvious question for the geneticist arises: Is it possible to select against skatole and androstenone in a breeding programme? Skatole is produced in the gut by bacteria. It is then absorbed in the blood stream. Skatole is either metabolised in the liver or transported and stored in fatty tissue. Androstenone is produced in the testis, and its biochemical pathway is related to the pathway of testosterone. In this study, fatty tissue was collected from the carcasses of Norwegian Landrace and Duroc boars, and analysed for androstenone and skatole. The length of glandula bulbourethralis was measured on the same animals, as this is regarded as a good indicator of sexual maturation. Heritabilities of androstenone and skatole were substantial. The two components were genetically correlated. Sexual maturation was also highly heritable. However, correlations to both androstenone and skatole were significantly unfavourable.
\end{abstract}

\section{Introduction}

In order to avoid boar taint from pork products, castration of male piglets has been common practice in most countries. In recent years focus has grown on animal welfare issues related to castration in several countries. In 2003 the Norwegian parliament voted for a new law regarding castration. After august 2003 anaesthetics have to be used and only veterinarians are allowed to castrate male piglets. Further, from 2009 castration of male piglets will no longer be permitted. This law introduces a substantial cost for the Norwegian pig production.

Boar taint is mainly caused by two components; androstenone and skatole. Skatole is produced in the large intes- tine by bacteria when metabolising tryptophan and absorbed in the blood stream. Skatole is either metabolised in the liver or transported and stored in fatty tissue. Androstenone is produced in the testis, and its biochemical pathway is related to the pathway of testosterone. An interesting question is whether the levels of androstenone and skatole in fatty tissue are heritable, and whether it is possible to reduce the levels by selection. Willeke [1] reports heritabilities of androstenone ranging from 0.25 to 0.87 . Sellier et al. [2] found heritablily of androstenone of 0.5 . Since androstenone is biochemically related to testosterone, investigating correlations between boar taint and sexual maturation is of major interest. Testicular steroids like androgens and oestrogens, are responsible for 
Table I: Number of records, means and standard deviations for Landrace boars

\begin{tabular}{lcrr}
\hline Trait & No. & Mean & Std. Dev. \\
\hline Androstenone (ppm) & 1728 & 1.19 & 1.10 \\
Ln(androstenone) & 1728 & -0.11 & 0.72 \\
Skatole (ppm) & 1372 & 0.10 & 0.17 \\
Ln(skatole) & 1372 & -2.76 & 0.89 \\
Indole (Ppm) & 1372 & 0.05 & 0.06 \\
Ln(Indole) & 1372 & -3.23 & 0.60 \\
Length(GBU) (cm) & 995 & 10.89 & 1.48 \\
\hline
\end{tabular}

the development of glandula bulbourethralis (GBU), an accessorial sexual gland [3]. GBU is therefore often used as an indicator of sexual maturation in male pigs [2]. Sellier et al. [2] found heritability of GBU to be 0.6 and genetic correlation between androstenone in fat and GBU of 0.65.

In Norway slaughter line measurements of skatole is based on a spectrophotometric method [4] where the output includes both skatole and indole. Indole is, like skatole, a product of bacterial degradation of tryptophan [5]. It is of interest to investigate the genetic correlation between skatole and indole to see whether this spectrophotometric method can be used directly in a selection process, or whether other methods discriminating skatole and indole should be applied.

The major objective of this study was to estimate heritabilities for androstenone and skatole and their genetic correlation in the Norsvin breeding populations; Landrace and Duroc. A second objective was to estimate the genetic correlation between skatole and indole and also genetic correlations between the boar taint components and sexual maturation of boars.

\section{Materials and methods}

The data used in this study was recorded on animals at Norsvins' boar test stations, which are a part of Norsvins' operative breeding programme. The boars are collected from nucleus farms at $25 \mathrm{~kg}$ live weight and grouped 12 pigs per pen where they stay until they reach $100 \mathrm{~kg}$ live weight. Some boars are culled directly from these pens after test, while others are moved to an individual pen where they stay until they are out competed in the boar selection process. This change of environment may potentially influence the level of boar taint. The Landrace and Duroc boars were on average 143 and 156 days at $100 \mathrm{~kg}$ live weight, respectively. For both breeds the boars were slaughtered on average 14 days later. The GBU were collected on the slaughter line and the length was measured. Subcutaneous fat were collected from the neck immediately after slaughter and stored at $-20^{\circ} \mathrm{C}$. Androstenone levels in fat were analysed using a modified time-resolved fluoroimmunoassay [6] using antiserum produced by Andresen [7]. Skatole and indole levels in fat were analysed using high-performance liquid chromatography [8].

The linear model to be used assumes normality. The distribution of androstenone, skatole and indole were skewed. Log-transforming the data reduced the problem of skeweness. Some animals had phenotypic levels below the detection limits of the chemo analytical methods used, and were recorded as zero. To avoid losing information by log-transformation the detection limits were added to all phenotypes before transformation. The detection limit is $0.05 \mathrm{ppm}$ for androstenone and $0.01 \mathrm{ppm}$ for skatole and indol. A summary of the phenotypes used in the analysis is presented in Tables 1 and 2.

Candidate fixed effects to be used in the variance component estimation were initially tested using the SAS Proc GLM procedure in SAS (SAS Inst., In., Cary, NC). The effects were kept in the model when significant $(p>0.10)$. Variance components were estimated using the DMU package, version 6 , release 4.5 [9]. The following multi trait model was used for the final analysis of all four phenotypes.

Table 2: Number of records, means and standard deviations for Duroc boars

\begin{tabular}{lcrr}
\hline Trait & No. & Mean & Std. Dev. \\
\hline Androstenone (Ppm) & 1202 & 3.27 & 2.52 \\
Ln(androstenone) & 1202 & 0.91 & 0.78 \\
Skatole (ppm) & 906 & 0.05 & 0.07 \\
Ln(skatole) & 906 & -3.40 & 0.91 \\
Indole (ppm) & 906 & 0.04 & 0.04 \\
Ln(Indole) & 906 & -3.35 & 0.53 \\
Length $(\mathrm{GBU})(\mathrm{cm})$ & 707 & 11.50 & 1.63 \\
\hline
\end{tabular}


Table 3: Genetic parameters for Landrace: Heritabilities on the diagonal, genetic correlations on the upper, right triangle and slaughter day \&error correlations on the lower left triangle

\begin{tabular}{lcccc}
\hline & $\ln (\mathrm{A})$ & $\ln (\mathrm{S})$ & $\ln (\mathrm{I})$ & $\mathrm{GBU}$ \\
\hline $\ln$ (Adrostenone) & $\mathbf{0 . 5 4}$ & 0.36 & 0.49 & 0.45 \\
$\ln$ (Skatole) & $0.51 \& 0.26$ & $\mathbf{0 . 5 5}$ & 0.82 & 0.35 \\
$\ln$ (Indole) & $0.69 \& 0.18$ & $0.84 \& 0.61$ & $\mathbf{0 . 3 8}$ & 0.48 \\
length(GBU) & $0.49 \& 0.32$ & $0.20 \& 0.19$ & $0.50 \& 0.15$ & $\mathbf{0 . 3 4}$ \\
\hline
\end{tabular}

Table 4: Genetic parameters for Duroc: Heritabilities on the diagonal, genetic correlations on the upper, right triangle and slaughter day \&error correlations on the lower left triangle

\begin{tabular}{lcccc}
\hline & $\ln (\mathrm{A})$ & $\ln (\mathrm{S})$ & $\ln (\mathrm{I})$ & $\mathrm{GBU}$ \\
\hline $\ln$ (Adrostenone) & $\mathbf{0 . 5 6}$ & 0.62 & 0.38 & 0.38 \\
$\ln$ (Skatole) & $-0.25 \& 0.32$ & $\mathbf{0 . 2 3}$ & 0.79 & 0.57 \\
$\ln$ (Indole) & $-0.06 \& 0.52$ & $0.43 \& 0.48$ & $\mathbf{0 . 2 6}$ & 0.53 \\
length(GBU) & $0.38 \& 0.40$ & $0.04 \& 0.14$ & $-0.15 \& 0.08$ & $\mathbf{0 . 5 7}$ \\
\hline
\end{tabular}

$=X b+Z_{1} s d+Z_{2} u+e$

where $\mathbf{y}$ is the phenotypic observations on log-transformed levels of androstenone, skatole and indole and GBU. The vector $\mathbf{b}$ includes the solutions of the fixed class effects herd*year*season and the effect of the boar being moved to an individual pen after $100 \mathrm{~kg}$ live weight. The b-vector also includes solutions of the covariates age at 25 $\mathrm{kg}$ live weight, days from 25 to $100 \mathrm{~kg}$ live weight and days from $100 \mathrm{~kg}$ live weight to slaughter. The vector sd is the random effect of slaughter day and $\mathbf{e}$ is the vector of residuals. The $\mathbf{u}$ vector includes the additive genetic effects. The matrices $\mathrm{X}, \mathrm{Z}_{1}$ and $\mathrm{Z}_{2}$ are known incident matrices.

\section{Results and discussion}

Heritabilities and correlations for Landrace and Duroc are presented in table 3 and 4 respectively. All genetic variance and covariance components were significant.

Androstenone levels are higher for Duroc than for Landrace. This agrees with the results of Xue et al. [10] and Squires and Lou [11]. Heritablilities of androstenone in both Landrace and Duroc were almost equally high. For skatole the level was lower in Duroc. Although skatole heritabilities in Duroc were less than half the size of the skatole heritability in Landrace, selecting against boar taint should clearly be possible if no other traits are considered. The genetic correlations between skatole and androstenone are positive. This makes selection against boar taint easier. The relatively high heritability of indole combined with the strong genetic correlation between indole and skatole shows that the spectrophotometric method for predicting skatole as the sum of skatole and indole may be a cost efficient alternative to a more costly but precise analysis of skatole. The genetic correlations etween boar taint components and GBU were positive, meaning unfavourable. Selection against boar taint will therefore most probably have a negative influence on sexual maturation of the boars. With correct weightings of traits it should be possible to reduce boar taint while putting restriction on sexual maturation. However, it is important to note that this will slow down progress compared to selection against boar taint only. Sellier et al. [2] did a selection experiment where the size of GBU increased while the level of androstenone were maintained. These results indicate that a combined selection may be possible.

\section{References}

I. Willeke $\mathrm{H}$ : Possibilities of breeding for low $5 \alpha$-adrostenone content in pigs. Pig News and Information 1993, 14:31-33.

2. Sellier P, Le Roy P, Fouilloux MN, Gruand J, Bonneau M: Responses to restricted index selection and genetic parameters for fat androstenone level and sexual maturity status of young boars. Livst Prod Sci 2000, 63:265-274.

3. Joshi HS, Raeside Jl: Synergistic effects of testosterone and oestrogens on accessory sex glands and sexual behaviour of the boar. J Reprod Fert 1973, 33:4| I-423.

4. Mortensen AB, Sørensen SE: Relationship between boar taint and skatole determined with a new analysis method. In Proceedings of the 30th Eurpoean meeting of meat research workers Bristol; 1984:394-396.

5. Deslandes B, Gariépy C, Houde A: Review of microbial and biochemical effects of skatole in animal production. Livest Prod Sci 200I, 71: I 93-200.

6. Tuomola M, Harpio R, Knuuttila P, Mikola H, Løvgren T: TimeResolved Fluoroimmunoassay for the Measurement of Androstenone in Porcine Serum and Fat Samples. J Agric Food Chem 1997, 45:3529-3534.

7. Andresen $\varnothing$ : Development of a radioimunoassay for $5 \alpha-$ adrost-16-en-3-one in pig peripheral plasma. Acta Endocrinologica 1974, 76:377-387.

8. Tuomola M, Vahva M, Kallio H: High-Performance Liquid Chromatography Determination of Skatole and Indole Levels in Pig Serum, Subcutaneous Fat and Submaxillary Salivary Glands. J Agric Food Chem 1996, 44: 1265-I270. , 
9. Madsen P, Jensen J: A User's Guide to DMU. In A package for analysing Multivariate mixed models Version 6, release 4.5.2005 DIAS, Foulum, Denmark.

10. Xue J, Dial GD, Holton EE, Vickers Z, Squires EJ, Lou Y, Godbout D, Morel N: Breed differences in boar taint: Relationship between tissue levels of boar taint compounds and sensory analysis of taint. J Anim Sci 1996, 74:2 I70-2। 77.

11. Squires EJ, Lou Y: Levels of boar taint in purebred entire male pigs in Canada. In From the Proceedings of the EAAP Working group on the Production and utilisation of Meat from Entire Male Pigs Milton Keynes, UK. Sept 27-29 1995

Publish with Bio Med Central and every scientist can read your work free of charge

"BioMed Central will be the most significant development for disseminating the results of biomedical research in our lifetime. " Sir Paul Nurse, Cancer Research UK

Your research papers will be:

- available free of charge to the entire biomedical community

- peer reviewed and published immediately upon acceptance

- cited in PubMed and archived on PubMed Central

- yours - you keep the copyright

Submit your manuscript here:

http://www.biomedcentral.com/info/publishing_adv.asp 